\title{
CAFE: An Instructional Design Model to Assist K-12 Teachers to Teach Remotely during and beyond the Covid-19 Pandemic
}

\author{
Charles Xiaoxue Wang ${ }^{1}$ (I) \\ Accepted: 26 October 2020 / Published online: 4 November 2020 \\ (C) Association for Educational Communications \& Technology 2020
}

\begin{abstract}
The impact of the COVID-19 global pandemic on schools was massive and unprecedented. Many schools were forced to close, and teachers were forced to deliver their instruction online with a very short notice. To assist K-12 teachers to teach remotely, a simple instructional design model, CAFE (Content, Activities, Facilitation, \& Evaluation), was created. This article describes the context in which CAFE was created and the three stages of improvement it went through from a simple instructional design table to the instructional design model. It also shares a reflection on the creation and characteristics of CAFE and finally, it ends with the introduction of the CAFE model.
\end{abstract}

Keywords Instructional design model $\cdot$ The COVID-19 pandemic $\cdot$ Remote teaching $\cdot$ Online teaching $\cdot$ CAFE instructional design model

\section{Introduction}

Most K-12 Teachers world-wide were not prepared for this sudden need and were forced to deliver their instructions online when the COVID-19 global pandemic hit schools. They were then and still are now working hard to transform their face-to-face classes into a virtual platform while simultaneously seeking a practical way to complete this daunting task. It was under such a circumstance that the Content, Activities, Facilitation, and Evaluation (CAFE) instructional design model was created to assist $\mathrm{K}-12$ teachers to complete this task. This article shares with the readers the development process of CAFE instructional design model to assist K-12 teachers to teach remotely (Hodges et al. 2020).

In the field of instructional design, there are many wellknown instructional design models such as ADDIE (Analysis, Design, Development, Implementation, and Evaluation) (Branch 2009), ASSURE by Smaldino et al. (2008), Systematic Design of Instruction by Dick et al. (2001), and the Morrison et al. (2010). These models, generally speaking, require extensive knowledge and professional

Charles Xiaoxue Wang

xxwang@fgcu.edu

1 Professor of Educational Technology, Florida Gulf Coast University, 10501 FGCU Blvd. S., Fort Myers, FL 33012, USA skills of instructional design to be able to flexibly and effectively use them in practice. They are certainly not a choice for many school teachers to meet their challenges during this COVID-19 pandemic school closure when they were in the reactive mode for instructional design.

CAFE is a simple instructional design model created specifically to assist K-12 teachers with transforming the classroom-based classes into "emergency remote teaching" (Hodges et al. 2020). It was created to address urgent needs of K-12 teachers with assumptions that K-12 teachers clearly understand the students, their learning needs, available technology and resources for learning at home, and their instructional content. This article describes how CAFE was created, tested, improved based on the feedback from its users and from instructional design experts, and finally evolved into a simple but well-used instructional design model that assisted many K-12 teachers to transform their classes online and teach them remotely.

\section{Start with Critical and Urgent Needs}

The COVID-19 global pandemic hit K-12 schools hard in many countries and forced K-12 teachers to adopt online instruction to minimize the negative impact of school closure on student learning. According to UNESCO Institute for Statistics data, by March 4, 2020, nearly 1.6 billion students 
were affected by COVID-19 global pandemic with 194 country-wide closures. These figures correspond to the number of learners enrolled at pre-primary, primary, secondary levels of education as well as those tertiary education levels, which constitute $91.3 \%$ of the total enrolled learners at these levels across the global (UNESCO 2020). As this pandemic happened so quickly and in such an unprecedent manner, one quick reaction many schools took was to shift their face-toface classes to remote teaching ones to keep learning going during the pandemic disruption. With a very short notice, many K-12 school teachers were forced to move their classes online and teach them remotely. Under such a circumstance, different teachers expressed varied needs in responding to remote teaching challenges.

To find out specific needs K-12 teachers face at the initial stage to transform their face-to-face classes online to keep learning going, a short survey of eight questions was sent out to a group of K-12 teachers as an email attachment. A total of 18 surveys were collected from China and then from the USA. The teachers who answered the survey were teaching different subjects including English, Reading, Social Science, and STEM (Science, Technology, Engineering, and Mathematics) courses in public and private schools. They were teach at different levels from primary schools, middle schools to high schools. Their ages ranged from 24 to 56 . Concurrently with the survey, a series of phone interviews with schoolteachers in China and locally in USA were conducted from beginning of January to the end of March 2020. Both the survey and the phone interviews with schoolteachers confirmed the critical and urgent needs they faced at the time:
- What should be included in my online class?

- How should I organize and present them in the required online learning platform?

- How should I teach remotely online?

- How do I know my students are learning?

To address these critical and urgent needs, a simple table was first created for K-12 teachers to assist them with their preparation for remote teaching (Table 1).

\section{Three Stages of Improvement for CAFE}

CAFE has gone through three stages of improvement. The improvement followed a circle of uses in the field, seeking for feedback and suggestions from its users, and revision based on the feedback and suggestions.

\section{Stage One}

In the first stage, the above table (Table 1) was sent to some $\mathrm{K}-12$ teachers and the comments and feedback later received were encouraging. However, requests for a better and clearer guidance were obvious. A teacher commented:

"The table certainly orients my thoughts to specific tasks and ensures me to go through all these tasks with a big picture of my class. However, some examples you included in the table are not clear to me. Who is Robert

Table 1 Original instructional design table

\begin{tabular}{|c|c|c|c|c|}
\hline Questions & $\begin{array}{l}\text { What should be included } \\
\text { in my online class? }\end{array}$ & $\begin{array}{l}\text { How should I organize and } \\
\text { present them in the required } \\
\text { online learning platform? }\end{array}$ & $\begin{array}{l}\text { How should I teach } \\
\text { remotely online? }\end{array}$ & $\begin{array}{l}\text { How do I know my } \\
\text { students are learning? }\end{array}$ \\
\hline Directions & $\begin{array}{l}\text { Organize your } \\
\text { instructional contents in } \\
\text { a week module }\end{array}$ & $\begin{array}{l}\text { Adapt your learning } \\
\text { activities for online } \\
\text { learning. }\end{array}$ & $\begin{array}{l}\text { Teach remotely with } \\
\text { synchronous } \\
\text { technology }\end{array}$ & $\begin{array}{l}\text { Adapt classroom test for } \\
\text { online assessment. }\end{array}$ \\
\hline Examples & $\begin{array}{l}\text { There are four weekly } \\
\text { units of instructions that } \\
\text { will be planned and } \\
\text { implemented. } \\
\text { Unit 1: Life Story of } \\
\text { Robert Frost and His } \\
\text { Poems. } \\
\text { There are } 4 \text { class hours } \\
\text { within this unit. } \\
\text { Lesson on will be Life } \\
\text { story of the Poet, Robert } \\
\text { Frost. }\end{array}$ & $\begin{array}{l}\text { List out functions in the } \\
\text { Learning Management } \\
\text { System (LMS) used by } \\
\text { your school. } \\
\text { Write an instruction for } \\
\text { searching online life } \\
\text { stories of Robert Frost. }\end{array}$ & $\begin{array}{l}\text { Inform the students and } \\
\text { parents of the } \\
\text { synchronous teaching } \\
\text { time. } \\
\text { Explain the requirement } \\
\text { and procedure of } \\
\text { activities with recorded } \\
\text { video message. }\end{array}$ & $\begin{array}{l}\text { Use quiz function of } \\
\text { LMS to test student. } \\
\text { Use essay questions and } \\
\text { grade students' paper. } \\
\text { Ask parents to grade and } \\
\text { provide comments and } \\
\text { feedback on student's } \\
\text { essay }\end{array}$ \\
\hline $\begin{array}{l}\text { It's your turn to answer these } \\
\text { questions. First, list out as many as } \\
\text { necessary in each column and then } \\
\text { order them. }\end{array}$ & & & & \\
\hline
\end{tabular}


frost, for example? Perhaps, you should include more explanations for the table."

The phone conversations with a local schoolteacher also suggested for a clearer guidance on these tasks. 'It's just not easy to understand what I should do. Maybe it's just me. Hope you could explain a bit more on these tasks."

Based on these comments and feedback, three major changes were made by (1) using task category labels to clarify the nature of the design tasks, (2) focusing on what needs to be done in its explanations, (3) removing confusing examples and (4) replacing them with commonly used activities for online instruction. Table 2, the improved instructional design table with CAFE task labels, was sent out to K-12 teachers and a few university faculty members to further test for its improvement.

\section{Stage Two}

The second stage of improvement was based on feedback received on the use of the instructional design table (Table 2). It was much better embraced by teachers this time. However, a couple of teachers (who were new in the profession) still kept asking for further explanations. Based on their comments and suggestions, CAFE was further improved by (1) adding visuals to illustrate the tasks. (2) improving task guide, and (3) adding in major functions of Canvas, a commonly used LMS in local school districts. In Activities, for example, what need to be done were further categorized and illustrated through "Prior to Activities," "During Activities," and "Post Activities" that orient teacher's thoughts on different aspects of activities in their design, development, and implementation. With these changes, CAFE was much easier to use and was much better received by its users in general.

\section{Stage Three}

However, one persistent new teacher called me a number of times asking for explanations of all those variables mentioned in CAFE. His persistence together with feedback received from expert instructional designers pushed CAFE into the third stage of improvement and made CAFE an instructional design model rather than a quick job-aid to react to an urgent instructional situation. In this stage, CAFE was sent to three colleagues, who are experts in the field of instructional design, for comments and suggestions. They pointed out that though most of the instructional design efforts by school teachers started as a reaction to the COVID-19 school closure, many school teachers soon have learned and adapted themselves to this type of new remote teaching. They began to move quickly beyond the initial reactive phase and into more active learning phase of remote teaching. As suggested by an

Table 2 Improved instructional design table

To Transform and Teach Your Class Online, You Need CAFE

\begin{tabular}{|c|c|c|c|}
\hline C: Content & A: Activities & F: Facilitation & E: Evaluation \\
\hline $\begin{array}{l}\text { Put your instructional contents } \\
\text { together in a systematic way. }\end{array}$ & $\begin{array}{l}\text { Design and develop a wide } \\
\text { variety of learning activities }\end{array}$ & $\begin{array}{l}\text { Facilitate (1) learner-content } \\
\text { interaction, (2) learner-instructor } \\
\text { interaction, and (3) learner-learner } \\
\text { Interaction online. }\end{array}$ & $\begin{array}{l}\text { Evaluate online learning performance } \\
\text { holistically. }\end{array}$ \\
\hline $\begin{array}{l}\text { - To organize instructional content } \\
\text { into weekly module and give a } \\
\text { title to each module. } \\
\text { - To identify the learning content } \\
\text { for each module, including } \\
\text { instructional materials and } \\
\text { resources needed. } \\
\text { - To list the order for material } \\
\text { presentation, specify their online } \\
\text { location and formats. }\end{array}$ & $\begin{array}{l}\text { - To locate or develop activities } \\
\text { for online learning. } \\
\text { - To write instructions for } \\
\text { carrying out the activities } \\
\text { including the medium and } \\
\text { presentation formats. } \\
\text { - To set activities up in Learning } \\
\text { Management System (LMS) } \\
\text { and test them before } \\
\text { launching. }\end{array}$ & $\begin{array}{l}\text { - To establish regular communications } \\
\text { with the class using email, } \\
\text { announcement, text, audio and } \\
\text { video messages. } \\
\text { - To use virtual office hours to answer } \\
\text { questions and support student } \\
\text { learning. } \\
\text { - To set up regular instructional time to } \\
\text { monitor student learning and } \\
\text { provide timely feedback and } \\
\text { encouragement. } \\
\text { - To create learning groups and } \\
\text { encourage student collaborations. }\end{array}$ & $\begin{array}{l}\text { - To understand LMS functions and } \\
\text { use multiple ways to evaluate } \\
\text { student online learning. } \\
\text { - To encourage peer evaluations. } \\
\text { - To evaluate student learning } \\
\text { holistically by using graded } \\
\text { assignments, online performance } \\
\text { and participation data. }\end{array}$ \\
\hline \multicolumn{4}{|c|}{ Start your work by writing in the cell of CAFE below for your own course. } \\
\hline \multicolumn{4}{|c|}{$\begin{array}{l}\text { Examples of Activities: } \\
\text { - Reflective Activities: Online Discussions \& writing a chapter summary. } \\
\text { - Productive Activities: Creating a plan for learning at home \& recording a video talk to tell a story. } \\
\text { - Synchronous Activities: Participating in a live class polling \& a synchronous discussion. }\end{array}$} \\
\hline
\end{tabular}


expert instructional designer, in addition to knowing what and how, teachers may also need to know why as some of pedagogical implications in CAFE might not be that obvious to them. This reminded us that effective technology integration for teachers requires knowledge of content, technology and pedagogy as illustrated by the TPACK framework (Mishra and Koehler 2006). The third stage of improvement for CAFE, according to the feedback from both teachers and experts of instructional design, added (1) a list of synthesized principles for remote teaching, (2) a revised illustration on facilitation of three types of interaction and their inter-connectedness responsible for student online learning, and (3) removed the rigid table that was not user-friendly. After these stages of improvement, CAFE began to establish as an instructional design model.

\section{Reflection}

At the reflection, it must be mentioned that this paper is not a research paper that reports the effects of CAFE instructional design model but shares the process of its development. The purpose of CAFE was to address urgent needs and to solve a practical problem of K-12 teachers during the COVID-19 pandemic school closure. It started with "identification of significant educational problems in need of innovative solutions" (McKenney and Reeves 2012, p. 14) and followed by an iterative process of testing and improving based on the user feedback and expert reviews. From a simple table to guide instructional design of schoolteachers as a quick job-aid, CAFE gradually evolved into an instructional design model that describes what need to be done to create instructions for remote teaching in a systematic way that is easy to understand for schoolteachers.

Like many other instructional design models, CAFE takes into consideration the specific context where schoolteachers generally have a good understanding of their students and learning contents but are unprepared for transforming their regular classes online for remote teaching in such a short notice. CAFE has visuals for easy and accurate comprehension of different categories of instructional design tasks. It is easy to use because it mirrors the ADDIE instructional design model, which describes "a systematic approach to instructional development" with an intuitive process that is not only "sequential but also iterative" (Molenda 2003, p. 34) in instructional design practice. However, CAFE helps its users by focusing on essential tasks and directly describes how to get the tasks done. In this sense, CAFE shares much of ADDIE elements and can be seen as a derivation from ADDIE as revealed by Table 3 .

When schoolteachers engaged in these categories of instructional design tasks as revealed in CAFE, multiple design elements were actually involved to ensure that
Table 3 Design elements of CAFE and ADDIE

\begin{tabular}{lllll}
\hline & Content & Activities & Facilitation & Evaluation \\
\hline Analysis & $\sqrt{ }$ & $\sqrt{ }$ & & \\
Design & $\sqrt{ }$ & $\sqrt{ }$ & & $\sqrt{ }$ \\
Development & $\sqrt{ }$ & $\sqrt{ }$ & & $\sqrt{ }$ \\
Implementation & & $\sqrt{ }$ & $\sqrt{ }$ & $\sqrt{ }$ \\
Evaluation & $\sqrt{ }$ & $\sqrt{ }$ & $\sqrt{ }$ & $\sqrt{ }$ \\
\hline
\end{tabular}

their instruction can be created effectively and in a systemic manner. To many of them, CAFE is a preferred instructional design model than others primarily because it was specifically created to address their urgent instructional design needs and has user-friendly characteristics. It affirms the nature of instructional design as solving real life problems in learning and teaching. Before the CAFE model is fully presented, it must be mentioned that some university faculty members, who used CAFE to create their online classes for remote teaching, have also complimented it for its easy-use, clear guide, and useful principles. These comments by university faculty members indicate the possible uses of CAFE beyond K-12 settings and in higher education. As a new instructional design model, it will be presented below for more critiques, comments, and suggestions for its further improvement.

\section{To Transform and Teach your Class Remotely Online, you Need CAFE}

The impacts of the COVID-19 global pandemic on schools and universities are massive. Teachers are working hard to transform their classes into a virtual platform while simultaneously seeking a practical way to complete this daunting task. In addition to many well-known instructional design models, such as ADDIE (Analysis, Design, Development, Implementation, and Evaluation) (Branch 2009), ASSURE by Smaldino et al. (2008), Systematic Design of Instruction by Dick et al. (2001), and Morrison et al. (2010), I would like to offer you a simple one called CAFE.

CAFE is a simple instructional design model to assist you with transforming the classroom-based classes into "emergency remote teaching" ones (Hodges et al. 2020). The assumptions are that you clearly understand your students, their learning needs, available technology and resources for learning at home and your instructional contents. CAFE offers some crucial considerations that guide you through from designing learning contents through evaluating your students' learning in a remote virtual setting (Figs. 1, 2, 3, 4 and 5). 


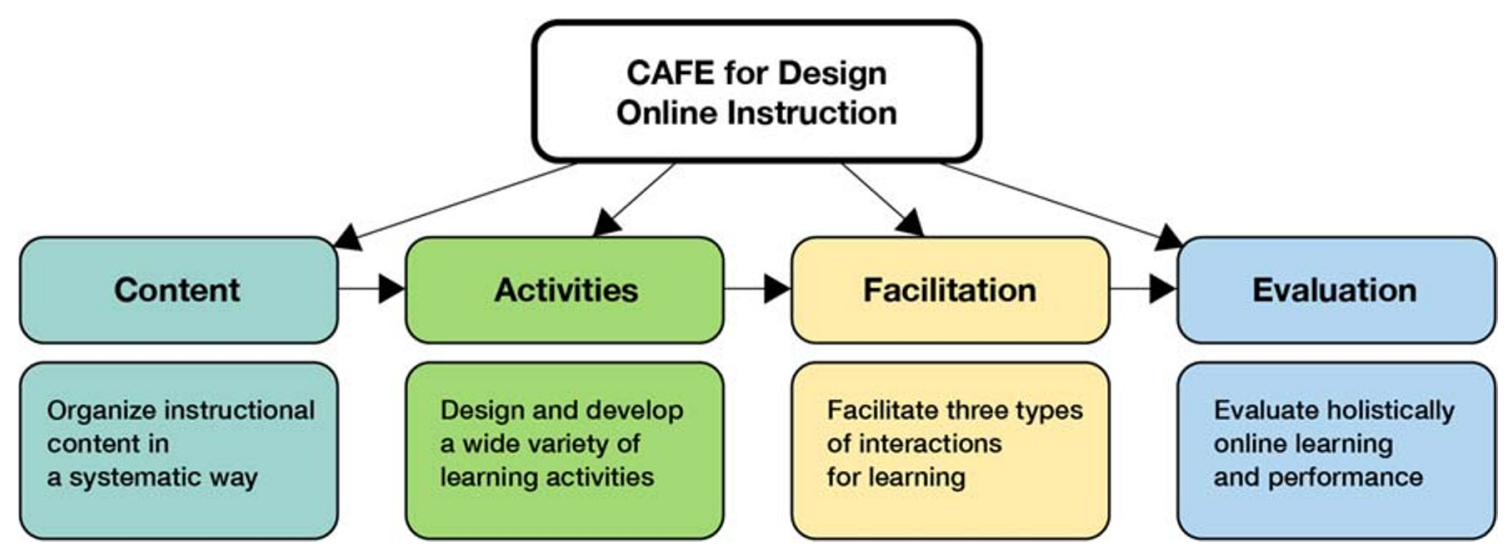

Fig. 1 CAFE for Design online instruction

Below is a brief explanation of the CAFE instructional design model.

\section{Content}

Organize your instructional content in a systematic way. You have four levels of content - Course, Module, Lesson, and Activities - you need to consider in this step as illustrated below.

- Course Level: Check your course content against your program requirements and standards. Make sure that they are well aligned with your program requirements and standards.
- Module Level: Organize your instructional contents for the semester into a weekly module. Give a title to each module and write out its instructional goals.

- Lesson Level: Identify the learning contents for each module first. You might have several instructional units or lessons within each module. Write out the title of each lesson for each module and list of learning outcomes/ objectives you want to achieve.

- Activity Level: List out all the needed materials for the lesson. This includes reading materials such as textbook chapters, activities, instructions on how to perform tasks in your remote class, assignments, project explanations, technological or other types of tools needed.

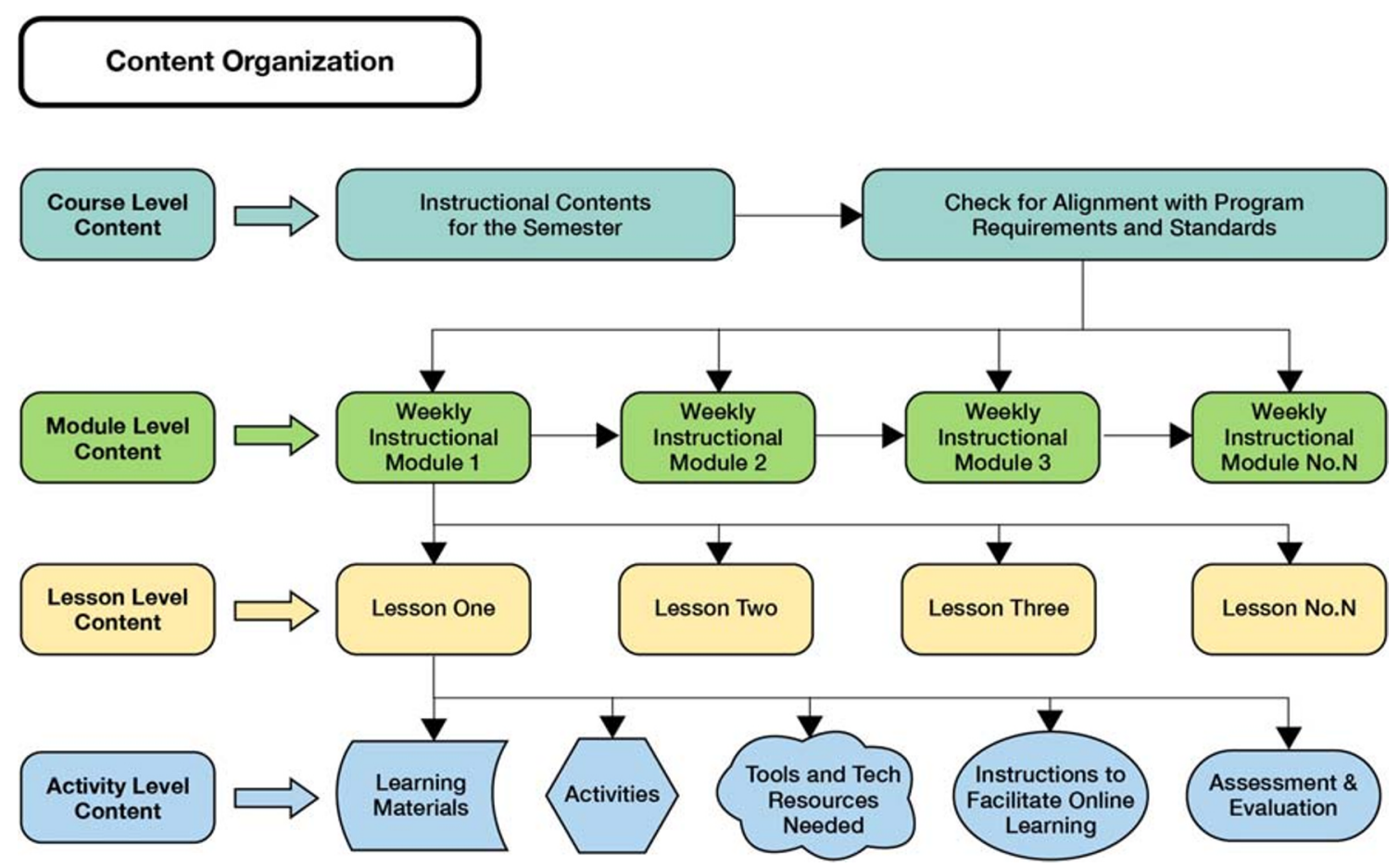

Fig. 2 Content organization 


\section{Activities for Learning}

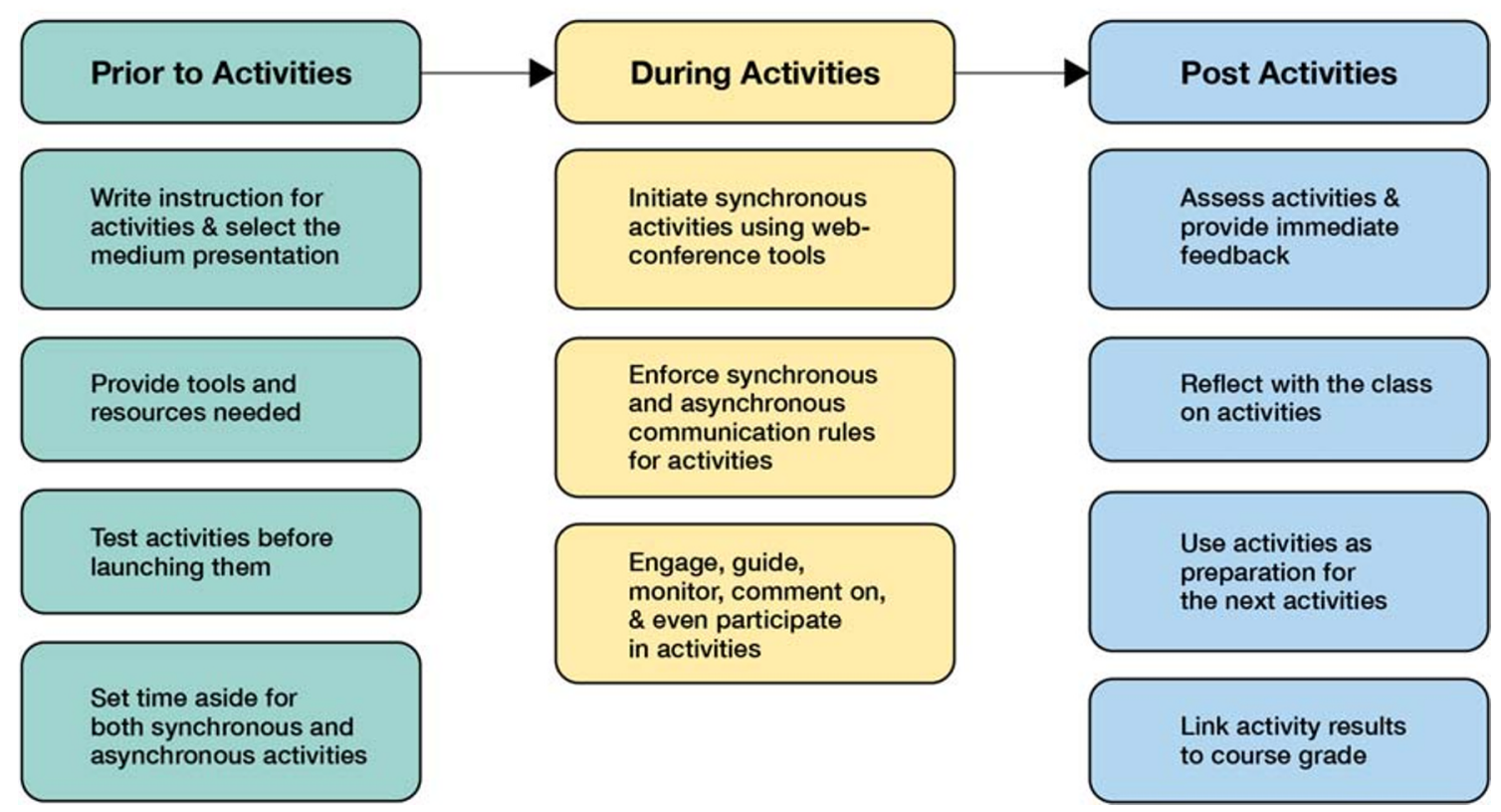

Fig. 3 Activities for learning

Have consistent expectations (repetitive structure) each week in the development of your instructional content. This will assist the K-12 students with developing a routine and engage in learning with less confusion.
Fig. 4 Learning variables and three types of interaction for learning

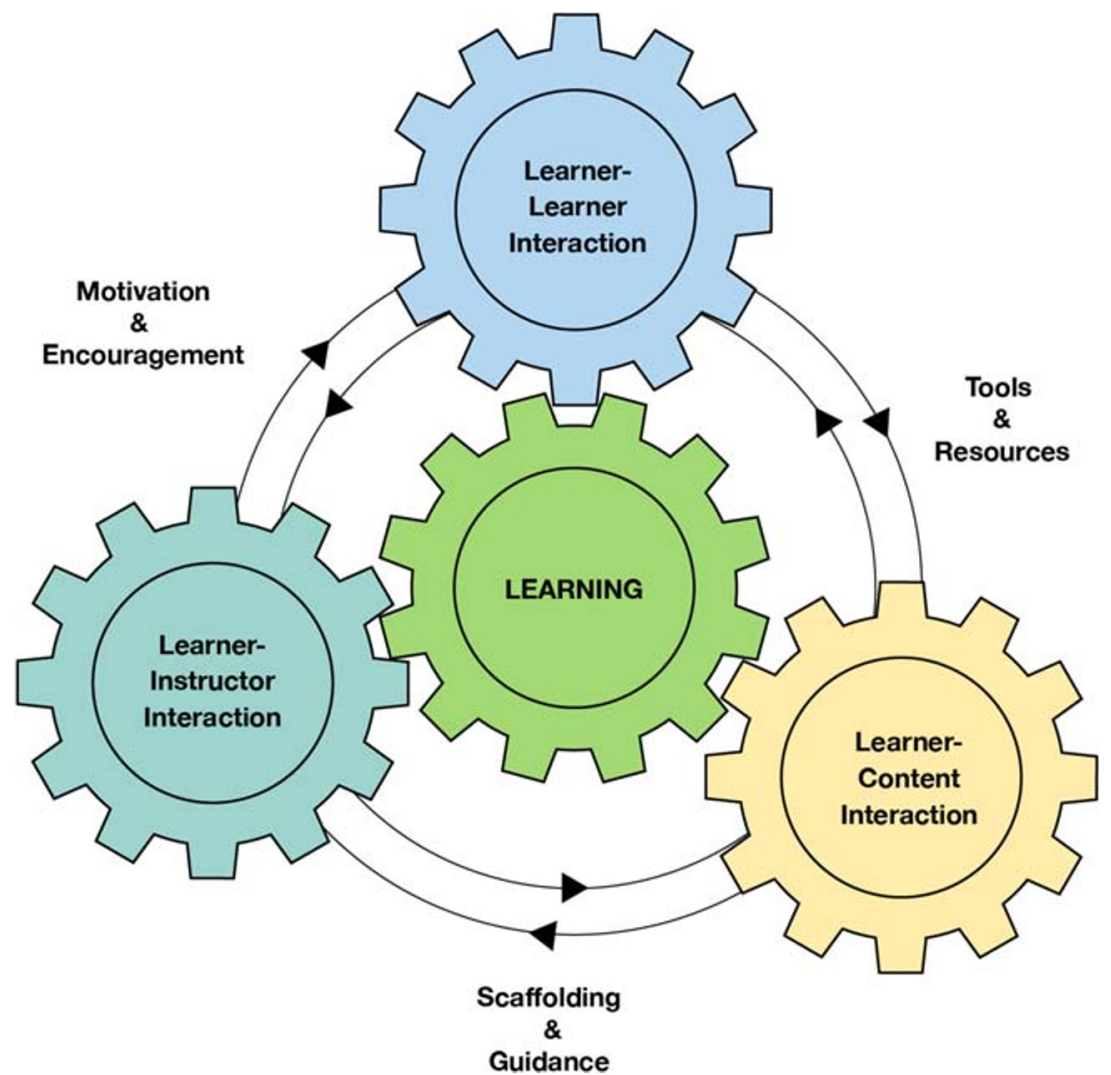




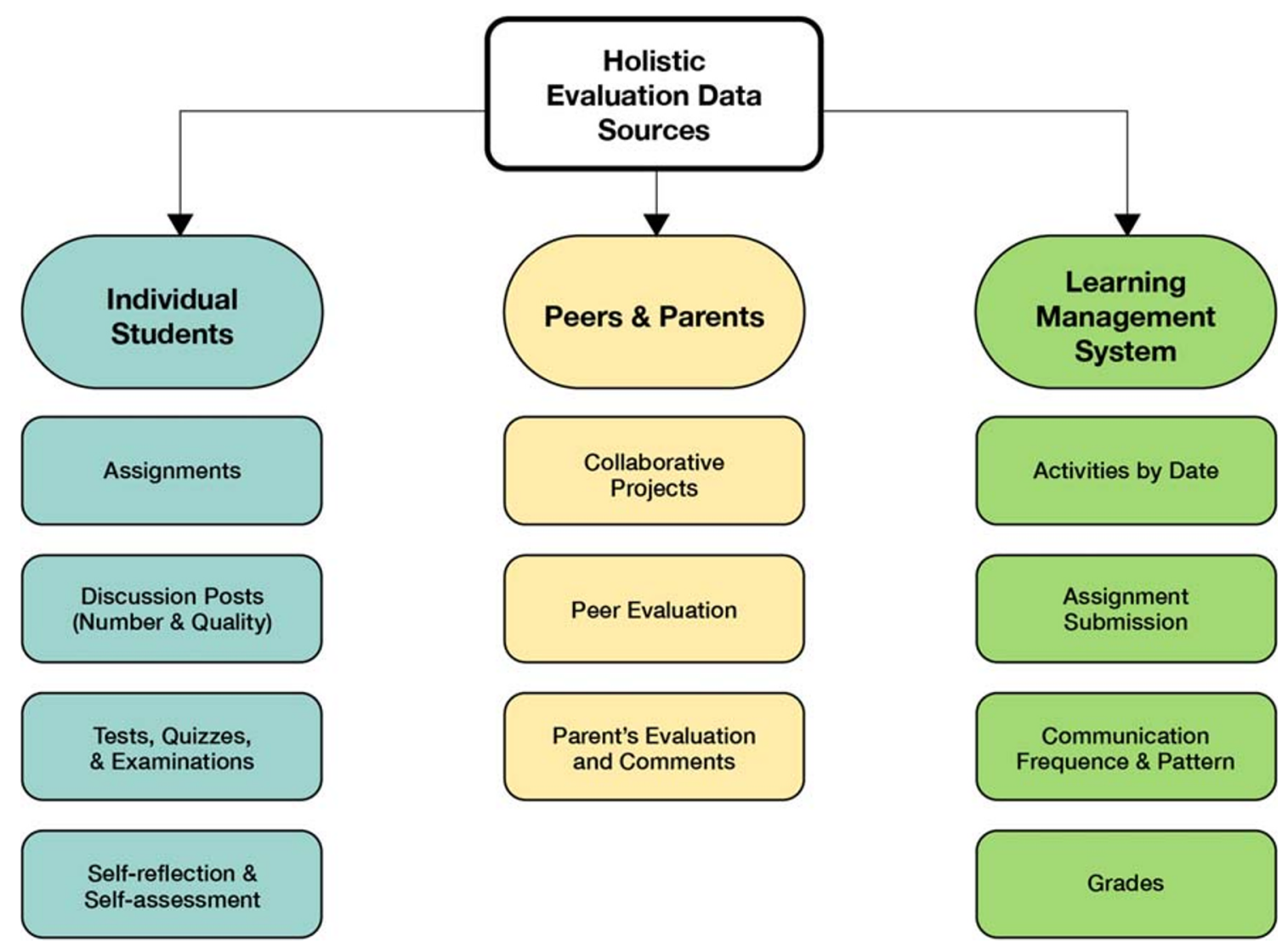

Fig. 5 Holistic evaluation data sources

\section{Activities}

Activities here refer to those organized learning efforts to help your students achieve learning objectives/outcomes you set up for your students. They can be a collaborative project, individual assignments, tests and quizzes, discussions, online explorations for problem solving. Organize your thoughts according to (1) Prior to the Activities, (2) During Activities, and (3) Post Activities.

Here are a few more considerations when you locate activities online or design and develop learning activities.

- If the learning activities are found online, make sure they are adapted to your own classroom situations and check for accessibility to make them compliant with ADA for students with disabilities.

- If you design and develop your own activities, ask a student to read your instructions to ensure they are clearly written. This will save you a lot of trouble down the road.

- When requiring students to complete a task that involves the use of a new platform, model the learning and provide examples for students.

- When setting activities up in a Learning Management System (LMS) such as Canvas, be sure to test them before launching. It is also very important to make them ADA compliant. There might be some students with disabilities sitting in your online class.

There are a wide variety of learning activities that can be used in your lessons. Some commonly-used online activities include:

- Reflective Activities: Online discussions, writing a chapter summary, or writing an argument.

- Productive Activities: Creating a plan for online learning, sharing a piece of newly-composed music, a collaborative writing project, or recording a video talk to synthesize a book chapter.

- Synchronous Activities: Participating in a live class polling, and synchronous online discussion forums.

- Asynchronous Activities: Sharing personal understanding of a chapter through social media, hosting an asynchronous discussion forum, or a math problem solving assignment.

\section{Facilitation}

Over 30 years ago, Moore (1989) listed three types of interaction responsible for distance and online learning: (1) 
learner-content interaction, (2) learner-instructor interaction, and (3) learner-learner interaction. These types of interaction can also be applied in an emergency remote teaching situation. Providing appropriate scaffolding and clear guidance, offering needed tools and resources, and motivating students to engage in these three types of interaction to help your students to achieve pre-established learning objectives.

Here are some tips or considerations for facilitating different types of interaction.

- Learner-Content Interaction: Use appropriate instructional materials in appropriate formats. It is easily said but not that easy to implement in an online class. Have a student proofread your materials or let them select material formats. If possible, offer your materials in multiple formats. Please consider adapting long reading materials into shorter sections to accommodate attention span for student learning at home. Also pay special attention to students with disabilities and make sure your online materials have gone through an ADA access check. Many LMSs have this function that you can use to check your materials online.

- Learner-Instructor Interaction: Establish regular communications with the class using text, audio, and video messages. Use virtual office hours to answer questions and to support student online learning. Set up a regular instructional time to monitor student learning and provide timely feedback and encouragement. In addition to using one-to-one communications with students, you can use one-to-group (e.g. group emails) and one-to-class communication (e.g. class announcements) to increase your communication efficiency. Change your communication formats occasionally and use more audio and video messages in addition to texts. These efforts will increase the teaching (social, cognitive, emotional) presence in your online classes.

- Learner-Learner Interaction: Create learning groups and encourage student collaboration. Embrace student differences in class. Ask some students to take a leadership role in learning so that they can learn from and help each other in your online class. Use learner-content interaction as a preparation for learner-learner interaction to ensure they read before sharing their thoughts and understanding in later discussions. Although this type of interaction is just between learners, you need to closely monitor it and frequently offer advice to some students whenever necessary. This ties closely to learner-instructor interaction as well.

For K-12, parent involvement is key here. Assist parents and offer them helpful hints and resources. In addition, perhaps provide training to encourage them to become your coteachers at home.

\section{Evaluation}

Evaluation of online learning can be challenging for many of us in an emergency remote teaching situation. Use multiple sources of data to evaluate student learning holistically is highly recommended.

Here are some considerations for holistic student evaluation:

- First, understand your LMS functions and use multiple ways to evaluate student learning. In addition to commonly used assessments such as testing, you can use their online performance data captured by your LMS to holistically evaluate student learning. These can be their contributions to class discussions, the number of times a student lead group projects, shared learning resources, or assisted others in learning.

- Encourage peer evaluations for collaborative projects. Consider inviting parents to evaluate their children's online learning at home.

- Use assessments and evaluation as an instructional means to promote student learning. In addition to promoting content mastery, self-assessments by students in any format can be used to train students to become reflective learners with enhanced self-regulated online learning skills.

\section{Final Words}

Many scholars (Chickering and Ehrmann 1996; Beldarrain 2006; Shih and Tsai 2017; Moore and Hodges 2020) have summarized principles for facilitating online learning and instruction and I have synthesized the following for you to consider.

- Encourage student and teacher communications through multiple formats (e.g. email, phone, social media, and web-conference platforms such as Zoom and Google Meets) and maintain its regularity.

- Communicate clearly high expectations for learning, requirements for learning tasks and activities, and rules for class communications and interaction.

- Set up virtual office hours to closely guide student learning, offer prompt feedback and timely encouragement to enhance the teaching (cognitive, social, \& emotional) presence of your classes.

- Respect diverse student talents and their ways of learning to create a safe and engaging online learning environment that allows multiple ways of responding and is ADA compliant.

- Use student self-assessment and peer assessment to promote self-regulated learning skills including time management and learning-progress monitoring skills. 
- Develop reciprocity and cooperation among students to boost the peer collaboration and peer support.

- Always summarize what has been learned at the end of each lesson and offer previews for the coming lessons.

I hope you can enjoy CAFE when transforming and teaching your classes remotely online. Here are some commonlyused functions in Canvas for presenting learning contents and activities:

- Modules: Use it for displaying all of the learning content and links to the learning activities such as assignments, tests, and discussions in each module.

- Pages: Use it to present learning instructions, and class announcements.

- Assignments: Use it for both gradable and non-gradable assignments \& individual and group assignments

- Discussions: Use it for class and group discussions. Discussions can be graded.

- Quizzes: Use it for tests in multiple formats. It can be multiple choice questions, true-false answers, or short answer questions. It also provides immediate feedback to students.

- Conference: Use it for synchronous communication activities like class discussions, online meetings, group collaborations and project work.

\section{Compliance with Ethical Standards}

Conflict of Interest I declare that there is no conflict of interest associate with the submitted manuscript.

Research Involving Human Participants and/or Animals The research was conducted by following all the ethical protocols that protects confidentiality and well-beings of people involved in the research.

Informed Consent It was obtained following the required research protocols.

\section{References}

Beldarrain, Y. (2006). Distance education trends: Integrating new technologies to foster student interaction and collaboration. Distance Education, 27(2), 139-153.

Branch, R, M. (2009). Instructional design: The ADDIE approach. New York: Springer.

Chickering, A. W., \& Ehrmann, S. C. (1996). Implementing the seven principles: Technology as lever. AAHE Bulletin, 49, 3-6.

Dick, W., Carey, L., \& Carey, J. O. (2001). The systematic design of instruction. 6th. New York: Longmann.

Hodges, C., Moore, S., Lockee, B., Trust, T., \& Bond, A. (2020). The difference between emergency remote teaching and online learning. Educause Review, 27.

McKenney, S, E., \& Reeves, T, C. (2012). Conducting educational design research. Routledge.

Mishra, P., \& Koehler, M. J. (2006). Technological pedagogical content knowledge: A new framework for teacher knowledge. Teachers College Record, 108(6), 1017-1054.

Molenda, M. (2003). In search of the elusive ADDIE model. Performance Improvement, 42(5), 34-37.

Moore, M. G. (1989). Editorial: Three types of interaction. American Journal of Distance Education, 3(2), 1-7. https://doi.org/10.1080/ 08923648909526659.

Moore, S., \& Hodges, C. (2020). So you want to temporarily teach online. Inside Higher Ed. Retrieved April 14, 2020, from https://www. insidehighered.com/advice/2020/03/11/practical-advice-instructorsfaced-abrupt-move-online-teaching-opinion.

Morrison, G. R., Ross, S. M., \& Kemp, J. E. ja Kalman, H.(2010). Designing effective instruction: Applications of instructional design. NJ: Wiley\& Sons.

Shih, W. L., \& Tsai, C. Y. (2017). Students' perception of a flipped classroom approach to facilitating online project-based learning in marketing research courses. Australasian Journal of Educational Technology, 33(5).

Smaldino, S., Heinich, R., Molenda, M., \& Russel, J. (2008). Instructional technology and media for learning. Upper Saddle River: Pearson Education, Inc.

UNESCO. "Education: From Disruption to Recovery." UNESCO, 15 June 2020, en.unesco.org/covid19/educationresponse.

Publisher's Note Springer Nature remains neutral with regard to jurisdictional claims in published maps and institutional affiliations. 